\title{
Chapter 19 \\ Commercial Products for Osteochondral Tissue Repair and Regeneration
}

\author{
Diana Bicho, Sandra Pina, Rui L. Reis, and J. Miguel Oliveira
}

\begin{abstract}
The osteochondral tissue represents a complex structure composed of four interconnected structures, namely hyaline cartilage, a thin layer of calcified cartilage, subchondral bone, and cancellous bone. Due to the several difficulties associated with its repair and regeneration, researchers have developed several studies aiming to restore the native tissue, some of which had led to tissue-engineered commercial products. In this sense, this chapter discusses the good manufacturing practices, regulatory medical conditions and challenges on clinical translations that should be fulfilled regarding the safety and efficacy of the new commercialized products. Furthermore, we review the current osteochondral products that are currently being marketed and applied in the clinical setting, emphasizing the advantages and difficulties of each one.
\end{abstract}

Keywords Commercial products · Bone, cartilage, and osteochondral regeneration

D. Bicho $(\triangle) \cdot$ S. Pina

3B's Research Group-Biomaterials, Biodegradables and Biomimetics, European Institute of Excellence on Tissue Engineering and Regenerative Medicine, University of Minho, Barco GMR, Portugal

ICVS/3B's—PT Government Associate Laboratory, Braga/Guimarães, Portugal e-mail: dianabicho@dep.uminho.pt

R. L. Reis · J. M. Oliveira

3B's Research Group-Biomaterials, Biodegradables and Biomimetics, European Institute of Excellence on Tissue Engineering and Regenerative Medicine, University of Minho, Barco GMR, Portugal

ICVS/3B's—PT Government Associate Laboratory, Braga/Guimarães, Portugal

The Discoveries Centre for Regenerative and Precision Medicine, University of Minho, Barco, Guimarães, Portugal 


\subsection{Introduction}

Treatment of bone and cartilage defects represents a current problem that needs to be solved. Although the present therapies are well established and effective for reducing pain, thus improving the patients' quality of life, the hyaline or articular cartilage has a limited regeneration capacity, demanding new therapeutic options for complete healing of the osteochondral (OC) lesions. In this sense, tissue engineered biomaterials for OC application present some key challenges regarding their biocompatibility, bioactivity, biodegradation, and biomechanical properties. Additionally, the ion release of metallic materials and the reproducibility of the techniques are also fundamental aspects to address [1]. Furthermore, the strategies applied need to present biodegradable with nontoxic degradation products of easy metabolization and excretion, well-regulated degradation kinetics and similar rate to native tissue. Similarly, the expected local or systemic immune responses should be controlled since it will affect significantly the implant-host integration. Most importantly, OC biomaterials should be able to mimic the extracellular matrix (ECM) and the complex mechanisms involved in the surrounding cells where the biomaterial will be applied [2]. The biomaterial chosen should be able to aid the cells to grow and proliferate at a similar natural rate, with an efficient gas and nutrients exchange [3]. Thus, the choice of the biomaterial is extremely important and needs to consider not only its chemical composition, but also its physical properties [4]. Specifically, in OC tissue engineering the mechanical properties must be able to bear the daily stress to which this tissue is subjected, as well as to support integration of the cells involved. Equally, the microstructure of the scaffold is essential for chondrogenesis and osteogenesis. Normally, it is believed that a superior cell ingrowth, improved transport of nutrient and vascular formation is related with high porosity $(>300 \mu \mathrm{m})$ [5] and interconnectivity $(>100 \mu \mathrm{m})$ of scaffolds to allow a proper cell colonization [6]. In regards to osteoinductive potential, there has been extensive research with some good synthetic materials having emerged, for example hydroxyapatite (HA), octacalcium phosphate (OCP), and $\beta$-tricalcium phosphate $(\beta$-TCP). However, regardless of their ability to be integrated into host tissues, they present poor mechanical properties, being therefore necessary to mix them with different materials that could overcome such limitations, and improve integration in OC lesions [7]. In addition, different natural and synthetic materials have been employed to engineer OC repair, presenting advantages and limitations. For instance, natural polymers are normally biocompatible and allow the interaction with cell receptors. However, safety concerns are usually an issue. In contrast, synthetic materials are more easily controllable and reproducible but lack the cell-recognition signals [8]. Researchers have suggested these materials to be especially used in the regeneration of large OC defects and sometimes combined with cells, growth factors, and tissue grafts [9].

Beside these scientific advances, when trying to launch new medical products and technologies to the market, several regulatory medical conditions should be fulfilled regarding their safety and efficacy. Moreover, regulatory hurdles associated with the commercialization of new products are critical. Therefore, laboratory facilities, manufacturing practices and documentation related to products development should 
follow strict requirements to ensure both the welfare of the individuals involved in the process and the reproducibility of the procedures. It is important to stress that all the directives involved in the manufacture and propagation of medical products and devices, can cause disagreements depending on the governmental administration involved. Among the multitude of options, Federal Food and Drug Administration (FDA) in the USA, and regional or centralized regulatory bodies like the European Medicines Agency (EMA) in the European Union (EU) are the most used. They are responsible for the development, assessment, and supervision of medicines [10]. Beyond this fact, it is also important to point out that the translations of the medical technologies into the clinic also rely on its nature, because cellular and acellular devices face different regulatory scrutiny in each country [11].

This chapter covers the general cares required for manufacturing tissue engineering and regenerative medicine (TERM) products. Particularly, it is focused the existing marketed products for OC tissue engineering and regeneration.

\subsection{Good Manufacturing Practices and Regulatory Hurdles in Tissue-Engineered Products}

Over the recent years, TERM has witnessed a rapid development that has motivated the marketing of novel products and with it some quality control procedures, and consistency and reproducibility guarantees. To assure that these conditions are being implemented, the FDA, EMA, and other world organizational committees are responsible to inspect the developers of commercial products. These organizations allow the implementation of standard procedures that extend away from individuals, research groups, and organizational procedures. It is their intention to have protocols in place that are independent of the operators and/or equipment guaranteeing uniformity of the data [12].

Good manufacturing practices (GMP) are a series of regulations that ensure that diagnostics, the production of pharmaceutical and medical devices, are controlled according to defined quality standards. GMP refers to all up-to-date aspects of the production from materials and equipment to the training staff and hygiene [13]. Moreover, the use of cells and tissues of human origin for TERM products also need to answer the good tissue practices (GTP). Particularly, GTP focuses its requirements on the prevention of the initiation, diffusion, and spread of contagious diseases besides ensuring uniformity, consistency, reliability, and reproducibility [14]. Following these lines, the description of a task or operation has to be performed in an identical manner and in compliance with appropriate regulation, as an approved standard operation procedure (SOP). Highly specific SOPs are usually required during all phases of a manufacturing process, and therefore are used to control the manufacturing of TERM products. Companies must agree to operate under harmonized guidelines across different geographic locations to assure that the best practices exist in every corner of the world. For instance, regarding TERM products using patient samples, companies need to pay attention to the appropriate ways to 
transport them once the classification of the shipment is the key in defining the level of containment required [13]. Fortunately, the TERM field is at the front line in terms of harmonization of international regulatory agencies, mostly because of the use of human cells in therapy, which has lead a worldwide joint effort [15]. Nevertheless, it should be kept in mind that the introduction of cells in tissueengineered materials has associated hazards such as teratoma formation, contamination, immunogenicity, and insufficient cell adaptation. Thus, even though the materials used for tissue engineered strategies affect the regulatory process, cellular scaffolds pass through more regulatory hurdles to assure their safety.

\subsection{Challenges in Clinical Translation and FDA Regulation}

The programs for safety regulation vary widely by the type of product, its potential risks, and the regulatory powers granted to the agency. For example, the FDA regulates almost every facet of prescription drugs, including testing, manufacturing, labeling, advertising, marketing, efficacy, and safety, yet FDA regulation of cosmetics focuses primarily on labeling and safety. The FDA regulates most products with a set of published standards enforced by a modest number of facility inspections [16]. Each type of material is subjected to a different type of regulation based on its classification. Therefore, it is possible to characterize devices as "substantially equivalent" to currently accepted devices, allowing them to be more easily commercialized [17]. Contrariwise, when using novel bioactive scaffolds it is necessary to deeply describe their degradation and safety profile in preclinical and clinical studies, which normally results in a $30 \%$ of the costs increment [11]. However, if possible, new materials with more refined features should be created for TERM applications despite the innumerous hurdles that ought to be addressed for eventual clinical success. The first aspect to keep in mind is the scientific basis and the patentability of the technology. Furthermore, clinical studies should be carefully conducted. Then, the company where the product has been developed needs to assure not only enough financial support but also the regulatory requirements for GMP in order to have reproducible products [12]. Finally, the market potential of the therapeutic solution, possible competitors, and target audience may be considered. Nevertheless, even with these concerns, TERM is experiencing a boost in the development of new therapies for the treatment of chronic diseases and damaged tissues.

\subsection{Commercially Available Products for Osteochondral Regeneration}

The commercialization process of the scaffolds for implantation involves multiple stages of R\&D replications before reaching the final approval from the government. R\&D stages ensure safety and efficacy of the implants, which involve the production of medical grade scaffolds followed by animal testing, under regulatory 
approved conditions. Over the recent years, the concentrated research on TERM has resulted in few clinically approved therapeutics. Biomaterials applied in tissue regeneration are normally composed of a temporary three-dimensional (3D) support for the growth of cells that will regenerate a given injury, being then biodegraded and substituted by the new tissue. In OC regeneration, different materials have been employed as templates for cell interactions and formation of ECM to support the newly formed tissue. However, the most commonly used technique consists in designing bilayered scaffolds able to regenerate both cartilage and subchondral bone [18]. Normally, autologous chondrocytes are seeded at the top of the scaffold and allows the application of a cell-scaffold implantation [19]. An alternative approach to this procedure uses two scaffolds from cartilage and bone assembled either before or during implantation to assure OC regeneration [20].

At the present time, some commercial products have appeared. For example, Collagraft ${ }^{\circledR}$ (Nuecoll Inc.) consists of a mixture of collagen with HA and $\beta$-TCP in the form of granules. In previous studies, this product was used as subchondral support using chondrocytes harvested from rabbit articular cartilage. The animal model used survived through the regenerative process which occurred after 6 months presenting the adequate features for bone integration, but not for cartilage [21]. On the other hand, the treatment of small OC defects is also possible with the collagenbased implant ChondroMimetic ${ }^{\mathrm{TM}}$ (TiGenix NV). This product is an off-the-shelf bilayer implant launched in the European market. The chondral layer is made of collagen and glycosaminoglycan while the osseous layer is composed of calcium phosphates. It showed to support the simultaneous natural repair mechanism of both articular cartilage and bone, following by implantation in patients [22]. Another collagen-based 3D scaffold to treat knee chondral or OC defects is MaioRegen ${ }^{\circledR}$ (Med\&Care). This matrix mimics the entire osteo-cartilaginous tissue and is composed of deantigenated type I equine collagen that resembles the cartilaginous tissue, and magnesium enriched-HA for the subchondral bone structure [23]. Preclinical studies using 12 sheep proved that this biomaterial is able to promote bone and hyaline-like cartilage tissue restoration. Quantitative macroscopic analysis showed absence of inflammation with some hyperemic synovium, but no synovial hypertrophy or fibrosis was noted. The histological score evaluations confirmed the presence of a newly formed tissue and a good integration of scaffolds [24]. Also, clinical evaluation of knee chondral and OC lesions in 27 patients, during a 5-year follow-up scored clinical improvements. Magnetic resonance imaging (MRI) results demonstrated a complete graft integration in $78.3 \%$ of patients offering a good clinical outcome for MaioRegen ${ }^{\circledR}$. However, in another clinical investigation using knee and talar OC injuries, the biological response in vivo evaluated over 2.5 years showing no improvements after the implantation of MaioRegen ${ }^{\circledR}$. Radiographic results of computed tomography and MRI presented a complete defect filling, integration, and an intact articular surface after 2.5 years of implantation [25].

One of the products used as an injectable material, in the treatment of OA of the knee, is the Gel-One ${ }^{\circledast}$, which is composed of a cross-linked hyaluronic acid hydrogel through a photo-gelation process [26]. This product was applied in a clinical study using 379 patients with OA, and a single injection allowed both the relief of the pain associated to this condition for 13 weeks, as well as physical improvements [27]. 
BST-Cargel $^{\circledR}$ (Piramal Life Sciences) has emerged as an advanced biodegradable and injectable chitosan hydrogel mixed with glycerophosphate and autologous blood to improve cartilage regeneration [28]. This off-the-shelf product can be used in conjunction with bone marrow cell stimulation by directly mixing blood from the patient with the biopolymer. This product has proved to be efficient in the initiation and amplification of the intrinsic wound healing processes of subchondral bone, as well as of the cartilage repair [28, 29]. An international randomized controlled trial with 80 patients was performed to compare the BST-Cargel ${ }^{\circledR}$ treatment with microfractured untreated patients. The results showed to be effective in the mid-term cartilage repair, and after 5-year follow up the treatment resulted in a sustained and significantly superior quantity and quality of repaired tissue against the microfracture alone [30]. Another commercial approach used in the treatment of cartilage defects, consists of a resorbable and textile polyglycolic acid-hyaluronan (PGA/ hyaluronan) implant named Chondrotissue ${ }^{\circledR}$ (Biotissue). In preclinical studies with an ovine animal model it has shown improved tissue formation [31]. Clinical results with 5-year follow-up registered that this product had a good safety profile and provided a good filling of the chondral defects of the knee [32]. The effects of Chondrotissue ${ }^{\circledR}$ in patella defects of the cartilage were also evaluated by first debriding the damaged cartilage down to the subchondral bone. Then, the immersion of the implant in venous blood allows an enhanced MSC recruitment and integration leading to the improvement of the symptoms and no intraoperative or postoperative complications [33]. Chondrocushion (Advanced Bio Surfaces, Inc) made of biphasic polyurethane cylinders is a synthethic product evaluated for cartilage application. This biomaterial presents some potential disadvantages related with the lack of porosity which impedes tissue ingrowth and replacement [34]. Other drawbacks of this type of product include the displacement of the implant site and the release of potentially toxic by-products that can cause inflammation and cell death [22, 35]. Another product within this category is SaluCartilage ${ }^{\mathrm{TM}}$ (SaluMedica), a biocompatible and hydrophilic cylindrical device consisting of a polyvinyl alcohol hydrogel. This material mimics human cartilage in terms of water proportions and has been evaluated as a synthetic surface for the replacement of damaged cartilage. There is no evidence of inflammatory reaction or osteolysis associated with this implant [35]. Correspondingly, clinical results showed improvement of the chondral defects, but the hydrogel showed inadequate connection to the bone and risk of dislocation [36].

TruGraft ${ }^{\mathrm{TM}}$ (Osteobiologics) is a poly(lactic-co-glycolic) acid (PLGA) granulate used as a bone void filler, and has shown to support osteoblast proliferation and differentiation proved by high alkaline phosphatase activity and deposition of a mineralized matrix used in OC repair [37]. Bioseed ${ }^{\circledR}-\mathrm{C}$ (Biotissue Technologies $\mathrm{GmbH}$ ) is a bioresorbable scaffold for OC composed of fibrin, PLA and polyglycoic acid (PGA) copolymer, and polydioxanone embedding chondrocytes [38]. This product was preclinically evaluated on an equine animal model of full thickness cartilage defects and showed capacity to be integrated while promoting the formation of cartilaginous tissue [39]. These promising results made the testing of this product proceed into humans with posttraumatic and degenerative cartilage defects of the knee 

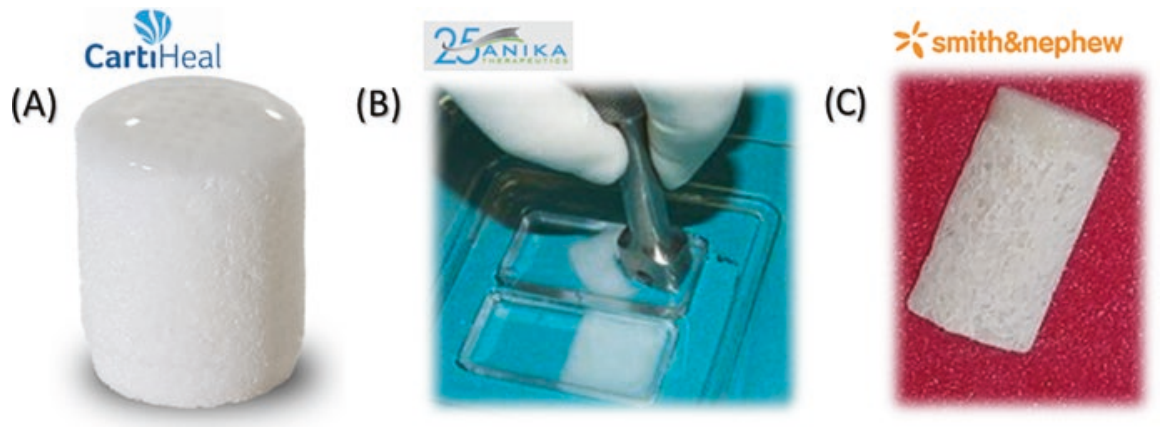

Fig. 19.1 Commercial biphasic scaffolds for osteochondral repair/regeneration: (a) Agili-C (reprinted with permission from [50]); (b) HYAFFTM (reprinted with permission from [51]. Copyright $@ 2015$, Springer Nature) and (c) Trufit ${ }^{\mathrm{TM}}$

$[40,41]$. It was reported that most of the grafts were able of completely fill the defects and formed tough hyaline-like cartilage, being well integrated into the tissue with good connection with the articular cartilage and the subchondral bone.

Feeding the importance of subchondral bone in the maintenance of articular cartilage, researchers have been developing some biphasic products in order to mimic both structures. These bilayered scaffolds have different characteristics to address different biological and functional requirements of both bone and cartilage, which are essential in the treatment of OC defects [23]. Accordingly, some commercial biphasic scaffolds are available in the market. For example, a product derived from natural sources for OC application, is Agili-C ${ }^{\mathrm{TM}}$ (CartiHeal) composed of calcium carbonate for the bone region, and aragonite and hyaluronic acid for the cartilage part (Fig. 19.1a). Results, after 12 months of implantation in a caprine animal model, showed an improvement in terms of cartilage repair and osteointegration with a reduction of the symptoms (limited motion, swelling of the joint, and pain). The bone phase of the implant shows a structure similar to natural bone presenting high pore interconnectivity essential for blood vessels [42, 43]. In contrast, the chondral phase rich in hyaluronic acid helps the ECM of the cartilage to be maintained with their proper characteristics. Kensey Nash Corporation started developing an acellular Cartilage Repair Device (CRD) to tackle primary defects of the articular cartilage in the joints, the OsseoFit ${ }^{\circledR}$ plug. This product was indicated to support the regeneration of hyaline cartilage and subchondral bone by promoting the correct cellular morphology, and structural organization during the healing process. The OsseoFit ${ }^{\circledR}$ plug is composed of a bioresorbable biphasic scaffold of collagen type-I fibrils, to simulate the cartilage, and $80 \% \beta$-TCP $+20 \%$ polylactic acid (PLA) for the subchondral bone phase. A study using OsseoFit ${ }^{\circledR}$ applied in 10 plugs on the medial femoral condyle and on the lateral femoral condyle displayed a reduction in height of the material and the integration of the product on the surrounding native cartilage [19]. HYAFF ${ }^{\circledR}$ (Fidia Advanced Biopolymers) is a biodegradable scaffold used for repair of chondral and OC lesions. It is composed of purified hyaluronan esterified in its glucuronic acid group with distinct types of alcohols (Fig. 19.1b). 
In vitro degradation profile of $\mathrm{HYAFF}^{\circledR} 11$ suggested that the hyaluronan esters undergo spontaneous deesterification in an aqueous environment, meaning a good integration in the biological tissues [44]. Also, in vivo studies showed a minimal response after the first month of implantation, and no evidence of toxicity during the 1-year study following implantation. HYAFF $^{\circledR} 11$ scaffolds present the advantage of having good cell adhesiveness even without coating and surface conditioning [45]. $\mathrm{TruFit}^{\circledR}$ (Smith \& Nephew) is another product used in OC applications (Fig. 19.1c) that consists of calcium phosphate and PLGA. This product presented good filling of OC defects, good integration in the native cartilage, and histological assays that showed a high percentage of hyaline cartilage formation, and good bone renovation after implantation in the femoral condyles and trochleae of goat defects [46]. Originally, this plug was designed as an alternative treatment for OC autologous transplantation, but in Europe has also been applied for acute focal articular cartilage and OC defects [47, 48]. Conversely, another work showed a comparative study between patients undergoing mosaicplasty (harvest and transplant of plugs of bone and cartilage from one place to another) and patients implanted with TruFit ${ }^{\circledR}$ showed no improvement in applying this product in comparison to the other procedure [49].

In order to establish a complete regenerative engineered strategy for TERM application, the use of cellular scaffolds has been proposed. The inclusion of living cells into the scaffolds enables real time growth factors, cytokines and matrix proteins which will accelerate the regenerative process. However, this technology also brings many complications besides the inevitable high costs, complexity of manufacture, sterility, preservation and regulatory issues. Currently, the application of cells without a scaffold has undergone several clinical studies showing that integration with the host tissue remains a problem [52]. This fact had led to the development of grafts combining living cells with biomaterials ex vivo allowing the construction of a 3D structure to be implanted in the living organism. Nevertheless, the type of cells and their quantity will help to set the mechanical and biochemical characteristics of the graft [53, 54]. The marketed product Osteoce ${ }^{\circledR}$ Plus $\left(\right.$ NuVasive $\left.{ }^{\circledR}\right)$ is an example of a cell-based bone graft. It contains native MSCs and osteoprogenitor cells combined with an osteoconductive demineralized bone matrix (DBM), and cancellous bone, presenting osteogenic capacity. Promising experiences with this material have been reported for several applications, including lumbar [55], as well as periodontal [56], foot and ankle defects [57].

On the other side, demineralized matrices from human donors are also applied as optimal biomaterials. An example is Dynagraft ${ }^{\circledR}$, a DBM combined with poloxamer, the nonionic triblock copolymer (GenSci Regeneration Sciences). This graft is moldable, packable and can be mixed with grafting materials being resistant to irrigation. Additionally, hyaluronate (i.e., DBX ${ }^{\circledR}$, Synthes), glycerol (Grafton ${ }^{\circledR}$, Osteotech, USA), and calcium sulfate (Allomatrix ${ }^{\circledR}$, Wright Medical Technology) have also been applied with DBM and are also being commercialized $[58,59]$. 
Commercially available cartilage graft BioCartilage ${ }^{\circledR}$ (Arthrex) provides a simple and inexpensive method to use extracellular cartilage matrix that has been dehydrated and micronized. It provides a proper scaffold to correct microfracture defects of articular cartilage, providing the appropriate biochemical signals, including collagen type II, cartilage matrix elements, and growth factors [60]. One of the few FDA approved ACT products is $\mathrm{Carticel}^{\circledR}$ (genzyme), which a cellular graft of autologous cultured cells derived from in vitro expansion of chondrocytes of femoral articular cartilage from the patient. The application of $\mathrm{Carticel}^{\circledR}$ in young patients has originated a cartilage tissue containing predominately collagen type II but lacking total host integration and alignment with the surrounding cartilage [61]. Hyalograft ${ }^{\oplus} \mathrm{C}$ is another commercially available matrix to assist chondrocyte implantation. This product is composed of a hyaluronic acid-based cartilage graft in combination with autologous isolated and enriched chondrocytes. The clinical data of the application of this product showed improvements in $91.5 \%$ of the patients $[62,63]$. The use of minced articular cartilage (autologous or allogeneic) defects is being explored for cartilage repair in OC defects. The off-the-shelf human tissue allograft DeNovo NT (Zimmer), consisting of juvenile hyaline cartilage pieces with viable chondrocytes, has emerged. This commercial product is intended to finds uses in lesions of articular cartilage. When implanting DeNovo NT, the debridement of the fibrous and calcified tissue of the defect should be performed without violating the subchondral bone layer. Then the implant is added to the lesion site and using fibrin glue will help the tissue to be maintained in place $[64,65]$. Recently, this juvenile particulate cartilage has been employed in patellar lesions with success. It has been demonstrated that the repair hyaline cartilage is performed by integration with the surrounding tissue showing a good recovery and improvement of the movements and reducing the pain associated with OC lesions [66]. Another alternative is the OC allograft Chondrofix ${ }^{\circledR}$ $\left(\right.$ Zimmer $^{\circledR}$ ) composed of decellularized cadaveric human joints consisting of hyaline cartilage and cancellous bone [67]. A case report of Chondrofix ${ }^{\circledR}$ implanted in a large full-thickness OC defect demonstrated to be completely incorporated by the bone without articular cartilage margins and restoring the native femoral condylar radius of curvature [68]. Nevertheless, when working with these types of materials, the risk of disease transmission or immunogenicity still remains. Moreover, they can be quite brittle leading to the accumulation of microfractures during the remodeling phase [69].

The available commercial products aforementioned show that there is still much research that needs to be done to create new therapies to significantly increase the regenerative capacity of OC structure. A summary of these commercialized products for bone, cartilage, and OC tissue regeneration is presented in Table 19.1. 
Table 19.1 Commercial products for the repair and regeneration of bone, cartilage, and OC defects

\begin{tabular}{|c|c|c|c|c|}
\hline Product & Manufacturer & Composition & Bioresorbable & Applications \\
\hline Chondromimetic $^{\mathrm{TM}}$ & TiGenix NV & Collagen, GAG, and CaP & $\checkmark$ & $\mathrm{OC}$ \\
\hline Trufit $^{\mathrm{TM}}$ & $\begin{array}{l}\text { Smith \& } \\
\text { Nephew }\end{array}$ & $\begin{array}{l}\text { Calcium sulfate, PLGA/ } \\
\text { PGA }\end{array}$ & $\checkmark$ & OC \\
\hline MaioRegen ${ }^{\circledR}$ & Med\&Care & $\begin{array}{l}\text { Collagen type I and } \\
\text { magnesium enriched-HA }\end{array}$ & $\checkmark$ & $\mathrm{OC}$ \\
\hline OsseoFit $^{\circledR}$ plug & & $\begin{array}{l}\text { Type I collagen, and } 80 \% \\
\beta-\text { TCP }+20 \% \text { PLA }\end{array}$ & $\checkmark$ & $\mathrm{OC}$ \\
\hline BST-Cargel $^{\circledR}$ & $\begin{array}{l}\text { Piramal Life } \\
\text { Sciences }\end{array}$ & $\begin{array}{l}\text { Chitosan gel, } \\
\text { glycerophosphate, and } \\
\text { autologous blood }\end{array}$ & n.d. & $\mathrm{OC}$ \\
\hline Bioseed $^{\circledR}-\mathrm{C}$ & $\begin{array}{l}\text { Biotissue } \\
\text { Technologies } \\
\text { GmbH }\end{array}$ & PLA/PGA & n.d. & OC \\
\hline Agili-C ${ }^{\text {TM }}$ & CartiHeal & $\begin{array}{l}\text { Calcium carbonate and } \\
\text { aragonite with hyaluronic } \\
\text { acid. }\end{array}$ & $\checkmark$ & $\mathrm{OC}$ \\
\hline Collagraft $^{\circledast}$ & Nuecoll Inc & $\begin{array}{l}\text { Collagen with granules } \\
\text { of HA and } \beta \text {-TCP }\end{array}$ & $\checkmark$ & OC \\
\hline Chondrotissue $^{\circledR}$ & Biotissue & PGA/hyaluronan & $\checkmark$ & Cartilage \\
\hline HYAFF $^{\circledR} 11$ & $\begin{array}{l}\text { Anika } \\
\text { Therapeutics }\end{array}$ & Hyaluronan & $\checkmark$ & $\begin{array}{l}\text { Cartilage and } \\
\text { OC }\end{array}$ \\
\hline Chondrocushion & $\begin{array}{l}\text { Advanced Bio } \\
\text { Surfaces, Inc }\end{array}$ & Polyurethane & No & Cartilage \\
\hline BST-Cargel $^{\circledR}$ & $\begin{array}{l}\text { Piramal Life } \\
\text { Sciences }\end{array}$ & $\begin{array}{l}\text { Chitosan with glycerol } \\
\text { phosphate and } \\
\text { autologous blood }\end{array}$ & $\checkmark$ & Cartilage \\
\hline SaluCartilage ${ }^{\mathrm{TM}}$ & SaluMedica & $\begin{array}{l}\text { Polyvinyl alcohol } \\
\text { hydrogel }\end{array}$ & $\checkmark$ & Cartilage \\
\hline Gel-One $^{\circledR}$ & Zimmer & Hyaluronic acid & n.d. & Knee OA \\
\hline
\end{tabular}

$n . d$ not defined, $G A G$ glycosaminoglycans, $C a P$ calcium phosphates, $O C$ osteochondral, PLGA poly(lactic-co-glycolic) acid, $H A$ hydroxyapatite, $P L A$ polylactic acid, $P G A$ polyglycolic acid, $O A$ osteoarthritis

\subsection{Concluding Remarks and Future Trends}

Several attempts are being made to mimic in vivo situations, and in fact enormous advances as regards not only to OC tissues but also to other tissues of the human body have been made. Herein, in this chapter we describe some commercial OC approaches, particularly based on 3D scaffolds envisioned to support newly formed tissues. The presented scaffolds are either biphasic, injectable hydrogels or decellularized matrices, and their outcomes reinforce the ideal basic requirements for the design of OC constructs aiming at tissue repair and regeneration. Such necessities include porosity, mechanical strength, biocompatibility, bioactivity, biodegradability, bio-integration, and proper cell proliferation and differentiation. Besides, due to 
its medical nature, new commercial products must undergo laborious testing, as demanded by regulatory approval bodies, before their use in humans. Therefore, some prospective improvements are under investigation to create better OC products. In this front, researchers are trying to enhance cell attachment to scaffolds using cell-adhesive ligands, and changing cell morphology, alignment, and phenotype, by varying the topographic surface of the scaffolds or even by mechanobiological stimulation of cells. Growth factors can also be incorporated directly into the scaffolds to help cells to differentiate, but immunomodulatory molecules are also an option to help to control inflammation towards the regenerative process. In the end, the final purpose is to create a scaffold that entirely mimics the ECM of OC tissue, having simultaneously proper mechanical properties, biochemical cues and the appropriate degradation profile, providing the ideal conditions for tissue growth.

Acknowledgments The authors acknowledge the project FROnTHERA (NORTE-01-0145FEDER-000023), supported by Norte Portugal Regional Operational Programme (NORTE 2020), under the PORTUGAL 2020 Partnership Agreement, through the European Regional Development Fund (ERDF). The authors would also like to acknowledge H2020-MSCA-RISE program, as this work is part of developments carried out in BAMOS project, funded by the European Union's Horizon 2020 research and innovation program under grant agreement $\mathrm{N}^{\circ} 734156$. The financial support from the Portuguese Foundation for Science and Technology under the program Investigador FCT 2012 and 2015 (IF/00423/2012 and IF/01285/2015) is also greatly acknowledged.

\section{References}

1. Bose S, Roy M, Bandyopadhyay A (2012) Recent advances in bone tissue engineering scaffolds. Trends Biotechnol 30:546-554. https://doi.org/10.1016/j.tibtech.2012.07.005

2. Benders KEM, van Weeren PR, Badylak SF et al (2013) Extracellular matrix scaffolds for cartilage and bone regeneration. Trends Biotechnol 31:169-176. https://doi.org/10.1016/j. tibtech.2012.12.004

3. Oliveira JT, Reis RL (2011) Polysaccharide-based materials for cartilage tissue engineering applications. J Tissue Eng Regen Med 5:421-436. https://doi.org/10.1002/term.335

4. Ge Z, Jin Z, Cao T (2008) Manufacture of degradable polymeric scaffolds for bone regeneration. Biomed Mater 3:22001. https://doi.org/10.1088/1748-6041/3/2/022001

5. Karageorgiou V, Kaplan D (2005) Porosity of 3D biomaterial scaffolds and osteogenesis. Biomaterials 26:5474-5491. https://doi.org/10.1016/j.biomaterials.2005.02.002

6. Habibovic P, Yuan H, van der Valk CM et al (2005) 3D microenvironment as essential element for osteoinduction by biomaterials. Biomaterials 26:3565-3575. https://doi.org/10.1016/j. biomaterials.2004.09.056

7. Pina S, Oliveira JM, Reis RL (2015) Natural-based nanocomposites for bone tissue engineering and regenerative medicine: a review. Adv Mater 27:1143-1169. https://doi.org/10.1002/ adma.201403354

8. Canadas RF, Pina S, Marques AP et al (2016) Cartilage and bone regeneration—how close are we to bedside? In: Transl. Regen. Med. to Clin. Elsevier, Amsterdam, pp 89-106

9. Giannoudis PV, Dinopoulos H, Tsiridis E (2005) Bone substitutes: an update. Injury 36:S20 S27. https://doi.org/10.1016/j.injury.2005.07.029

10. Van Norman GA (2016) Drugs and devices: comparison of European and U.S. approval processes. JACC Basic Transl Sci 1:399-412. https://doi.org/10.1016/j.jacbts.2016.06.003 
11. Webber MJ, Khan OF, Sydlik SA et al (2014) A perspective on the clinical translation of scaffolds for tissue engineering. Ann Biomed Eng 43:641-656. https://doi.org/10.1007/ s10439-014-1104-7

12. Dodson BP, Levine AD (2015) Challenges in the translation and commercialization of cell therapies. BMC Biotechnol 15:70. https://doi.org/10.1186/s12896-015-0190-4

13. Basu J, Ludlow JW (2012) Regulatory and quality control. Dev Tissue Eng Regen Med Prod A Pract Approach 125-148. https://doi.org/10.1533/9781908818119.125

14. Idowu B, Di Silvio L (2013) Principles of good laboratory practice (GLP) for in vitro cell culture applications. Stand Cell Tissue Eng Methods Protoc 127-147. https://doi. org/10.1533/9780857098726.2.127

15. Gálvez P, Clares B, Hmadcha A et al (2013) Development of a cell-based medicinal product: regulatory structures in the European Union. Br Med Bull 105:85-105. https://doi.org/10.1093/ $\mathrm{bmb} / \mathrm{lds} 036$

16. Tyler RS (2013) The goals of FDA regulation and the challenges of meeting them. Health Matrix Clevel 22:423-431

17. Lewin A (2012) Medical device innovation in America: tensions between food and drug law and patent law. Harv J Law Technol 26

18. Dormer NH, Berkland CJ, Detamore MS (2010) Emerging techniques in stratified designs and continuous gradients for tissue engineering of interfaces. Ann Biomed Eng 38:2121-2141. https://doi.org/10.1007/s10439-010-0033-3

19. Elguizaoui S, Flanigan DC, Harris JD et al (2012) Proud osteochondral autograft versus synthetic plugs - contact pressures with cyclical loading in a bovine knee model. Knee 19:812817. https://doi.org/10.1016/j.knee.2012.03.008

20. Swieszkowski W, Tuan BHS, Kurzydlowski KJ, Hutmacher DW (2007) Repair and regeneration of osteochondral defects in the articular joints. Biomol Eng 24:489-495. https://doi. org/10.1016/j.bioeng.2007.07.014

21. Schaefer D, Martin I, Jundt G et al (2002) Tissue-engineered composites for the repair of large osteochondral defects. Arthritis Rheum 46:2524-2534. https://doi.org/10.1002/art.10493

22. Getgood A, Henson F, Skelton C et al (2014) Osteochondral tissue engineering using a biphasic collagen/GAG scaffold containing rhFGF18 or BMP-7 in an ovine model. J Exp Orthop 1:13. https://doi.org/10.1186/s40634-014-0013-x

23. Kon E, Delcogliano M, Filardo G et al (2009) Novel nano-composite multi-layered biomaterial for the treatment of multifocal degenerative cartilage lesions. Knee Surg Sport Traumatol Arthrosc 17:1312-1315. https://doi.org/10.1007/s00167-009-0819-8

24. Kon E, Delcogliano M, Filardo G et al (2010) Orderly osteochondral regeneration in a sheep model using a novel nano-composite multilayered biomaterial. J Orthop Res 28:n/a. https:// doi.org/10.1002/jor.20958

25. Christensen BB, Foldager CB, Jensen J et al (2016) Poor osteochondral repair by a biomimetic collagen scaffold: 1- to 3-year clinical and radiological follow-up. Knee Surg Sport Traumatol Arthrosc 24:2380-2387. https://doi.org/10.1007/s00167-015-3538-3

26. Ishikawa M, Yoshioka K, Urano K et al (2014) Biocompatibility of cross-linked hyaluronate (Gel-200) for the treatment of knee osteoarthritis. Osteoarthr Cartil 22:1902-1909. https://doi. org/10.1016/j.joca.2014.08.002

27. Strand V, Baraf HSB, Lavin PT et al (2012) A multicenter, randomized controlled trial comparing a single intra-articular injection of Gel-200,?a?new cross-linked formulation of hyaluronic acid, to phosphate buffered saline for treatment of osteoarthritis of the knee. Osteoarthr Cartil 20:350-356. https://doi.org/10.1016/j.joca.2012.01.013

28. Stanish WD, McCormack R, Forriol F et al (2013) Novel scaffold-based BST-CarGel treatment results in superior cartilage repair compared with microfracture in a randomized controlled trial. J Bone Jt Surg Am 95:1640-1650. https://doi.org/10.2106/JBJS.L.01345

29. Shive MS, Hoemann CD, Restrepo A et al (2006) BST-CarGel: in situ chondroinduction for cartilage repair. Oper Tech Orthop 16:271-278. https://doi.org/10.1053/j.oto.2006.08.001

30. Shive MS, Stanish WD, McCormack R et al (2015) BST-CarGel® treatment maintains cartilage repair superiority over microfracture at 5 years in a multicenter randomized controlled trial. Cartilage 6:62-72. https://doi.org/10.1177/1947603514562064 
31. Erggelet C, Endres M, Neumann K et al (2009) Formation of cartilage repair tissue in articular cartilage defects pretreated with microfracture and covered with cell-free polymer-based implants. J Orthop Res 27:1353-1360. https://doi.org/10.1002/jor.20879

32. Siclari A, Mascaro G, Gentili C et al (2014) Cartilage repair in the knee with subchondral drilling augmented with a platelet-rich plasma-immersed polymer-based implant. Knee Surg Sport Traumatol Arthrosc 22:1225-1234. https://doi.org/10.1007/s00167-013-2484-1

33. Becher C, Ettinger M, Ezechieli M et al (2015) Repair of retropatellar cartilage defects in the knee with microfracture and a cell-free polymer-based implant. Arch Orthop Trauma Surg 135:1003-1010. https://doi.org/10.1007/s00402-015-2235-5

34. McNickle AG, Provencher MT, Cole BJ (2008) Overview of Existing Cartilage Repair Technology. Sports Med Arthrosc 16:196-201. https://doi.org/10.1097/ JSA.0b013e31818cdb82

35. Falez F, Sciarretta FV (2015) Treatment of osteochondral symptomatic defects of the knee with salucartilage. Orthop Proc 87-B

36. Lange J, Follak N, Nowotny T, Merk H (2006) Ergebnisse der SaluCartilage-implantation bei viertgradigen Knorpelschäden im Bereich des Kniegelenks. Unfallchirurg 109:193-199. https://doi.org/10.1007/s00113-005-1025-x

37. Ishaug-Riley SL, Crane-Kruger GM, Yaszemski MJ, Mikos AG (1998) Three-dimensional culture of rat calvarial osteoblasts in porous biodegradable polymers. Biomaterials 19:14051412. https://doi.org/10.1016/S0142-9612(98)00021-0

38. Demoor M, Ollitrault D, Gomez-Leduc T et al (2014) Cartilage tissue engineering: Molecular control of chondrocyte differentiation for proper cartilage matrix reconstruction. Biochim Biophys Acta Gen Subj 1840:2414-2440. https://doi.org/10.1016/j.bbagen.2014.02.030

39. Barnewitz D, Endres M, Krüger I et al (2006) Treatment of articular cartilage defects in horses with polymer-based cartilage tissue engineering grafts. Biomaterials 27:2882-2889. https:// doi.org/10.1016/j.biomaterials.2006.01.008

40. Kreuz PC, Müller S, Ossendorf C et al (2009) Treatment of focal degenerative cartilage defects with polymer-based autologous chondrocyte grafts: four-year clinical results. Arthritis Res Ther 11:R33. https://doi.org/10.1186/ar2638

41. Ossendorf C, Kaps C, Kreuz PC et al (2007) Treatment of posttraumatic and focal osteoarthritic cartilage defects of the knee with autologous polymer-based three-dimensional chondrocyte grafts: 2-year clinical results. Arthritis Res Ther 9:R41. https://doi.org/10.1186/ar2180

42. Guillemin G, Patat J-L, Fournie J, Chetail M (1987) The use of coral as a bone graft substitute. J Biomed Mater Res 21:557-567. https://doi.org/10.1002/jbm.820210503

43. Kon E, Filardo G, Shani J et al (2015) Osteochondral regeneration with a novel aragonitehyaluronate biphasic scaffold: up to 12-month follow-up study in a goat model. J Orthop Surg Res 10:81. https://doi.org/10.1186/s13018-015-0211-y

44. Zhong SP, Campoccia D, Doherty PJ et al (1994) Biodegradation of hyaluronic acid derivatives by hyaluronidase. Biomaterials 15:359-365

45. Campoccia D, Doherty P, Radice M et al (1998) Semisynthetic resorbable materials from hyaluronan esterification. Biomaterials 19:2101-2127. https://doi.org/10.1016/ S0142-9612(98)00042-8

46. Iii RJW, Gamradt SC, Williams RJ (2008) Articular cartilage repair using a resorbable matrix scaffold. Instr Course Lect 57:563-571

47. Melton JT, Wilson AJ, Chapman-Sheath P, Cossey AJ (2010) TruFit CB ® bone plug: chondral repair, scaffold design, surgical technique and early experiences. Expert Rev Med Devices 7:333-341. https://doi.org/10.1586/erd.10.15

48. Carmont MR, Carey-Smith R, Saithna A et al (2009) Delayed Incorporation of a TruFit Plug: perseverance is recommended. Arthrosc J Arthrosc Relat Surg 25:810-814. https://doi. org/10.1016/j.arthro.2009.01.023

49. Hindle P, Hendry JL, Keating JF, Biant LC (2014) Autologous osteochondral mosaicplasty or TruFit ${ }^{\circledR}$ plugs for cartilage repair. Knee Surg Sport Traumatol Arthrosc 22:1235-1240. https:// doi.org/10.1007/s00167-013-2493-0

50. Kon E, Filardo G, Perdisa F et al (2014) Clinical results of multilayered biomaterials for osteochondral regeneration. J Exp Orthop 1:10. https://doi.org/10.1186/s40634-014-0010-0 
51. Buda R, Vannini F, Castagnini F et al (2015) Regenerative treatment in osteochondral lesions of the talus: autologous chondrocyte implantation versus one-step bone marrow derived cells transplantation. Int Orthop 39:893-900. https://doi.org/10.1007/s00264-015-2685-y

52. Worthen J, Waterman BR, Davidson PA, Lubowitz JH (2012) Limitations and sources of bias in clinical knee cartilage research. Arthrosc J Arthrosc Relat Surg 28:1315-1325. https://doi. org/10.1016/j.arthro.2012.02.022

53. Bertolo A, Mehr M, Aebli N et al (2012) Influence of different commercial scaffolds on the in vitro differentiation of human mesenchymal stem cells to nucleus pulposus-like cells. Eur Spine J 21(Suppl 6):S826-S838. https://doi.org/10.1007/s00586-011-1975-3

54. Chen RR, Mooney DJ (2003) Polymeric growth factor delivery strategies for tissue engineering. Pharm Res 20:1103-1112. https://doi.org/10.1023/A:1025034925152

55. Ammerman JM, Libricz J, Ammerman MD (2013) The role of Osteocel Plus as a fusion substrate in minimally invasive instrumented transforaminal lumbar interbody fusion. Clin Neurol Neurosurg 115:991-994. https://doi.org/10.1016/j.clineuro.2012.10.013

56. McAllister BS (2011) Stem cell-containing allograft matrix enhances periodontal regeneration: case presentations. Int J Periodontics Restorative Dent 31:149-155

57. Scott RT, Hyer CF (2013) Role of cellular allograft containing mesenchymal stem cells in highrisk foot and ankle reconstructions. J Foot Ankle Surg 52:32-35. https://doi.org/10.1053/j. jfas.2012.09.004

58. Dhandayuthapani B, Yoshida Y, Maekawa T, Kumar DS (2011) Polymeric scaffolds in tissue engineering application: a review. Int J Polym Sci. https://doi.org/10.1155/2011/290602

59. Drosos GI (2015) Use of demineralized bone matrix in the extremities. World J Orthop 6:269. https://doi.org/10.5312/wjo.v6.i2.269

60. Abrams GD, Mall NA, Fortier LA et al (2013) BioCartilage: background and operative technique. Oper Tech Sports Med 21:116-124. https://doi.org/10.1053/j.otsm.2013.03.008

61. Kurkijärvi JE, Mattila L, Ojala RO et al (2007) Evaluation of cartilage repair in the distal femur after autologous chondrocyte transplantation using T2 relaxation time and dGEMRIC. Osteoarthr Cartil 15:372-378. https://doi.org/10.1016/j.joca.2006.10.001

62. Gobbi A, Kon E, Berruto M et al (2009) Patellofemoral full-thickness chondral defects treated with second-generation autologous chondrocyte implantation. Am J Sports Med 37:10831092. https://doi.org/10.1177/0363546509331419

63. Marcacci M, Berruto M, Brocchetta D, et al (2005) Articular cartilage engineering with hyalograft(R) C: 3-year clinical results. [Report]. Clin Orthop Relat Res 96-105

64. Tompkins M, Adkisson HD, Bonner KF (2013) DeNovo NT allograft. Oper Tech Sports Med 21:82-89. https://doi.org/10.1053/j.otsm.2013.03.005

65. Kruse DL, Ng A, Paden M, Stone PA (2012) Arthroscopic de novo NT? juvenile allograft cartilage implantation in the talus: a case presentation. J Foot Ankle Surg 51:218-221. https:// doi.org/10.1053/j.jfas.2011.10.027

66. Buckwalter JA, Bowman GN, Albright JP et al (2014) Clinical outcomes of patellar chondral lesions treated with juvenile particulated cartilage allografts. Iowa Orthop J 34:44-49

67. Gomoll AH (2013) Osteochondral allograft transplantation using the chondrofix implant. Oper Tech Sports Med 21:90-94. https://doi.org/10.1053/j.otsm.2013.03.002

68. Reynolds KL, Bishai SK (2014) In situ evaluation of chondrofix(registered trademark) osteochondral allograft 25 months following implantation: a case report. Osteoarthr Cartil 22:S155S156. https://doi.org/10.1016/j.joca.2014.02.288

69. Horton MT, Pulido PA, McCauley JC, Bugbee WD (2013) Revision osteochondral allograft transplantations. Am J Sports Med 41:2507-2511. https://doi.org/10.1177/0363546513500628 